\title{
Egészségtudatos magatartás vizsgálata a Debreceni Egyetem Gazdaságtudományi Kar sportszakos hallgatói körében
}

\section{Research of Healthy Behavior at Faculty of Economic Sciences' sport sciences' students at the University of Debrecen}

\author{
Zs. KoroKNAY1 ${ }^{1}$ C. PFAU ${ }^{2}$ \\ ${ }^{1}$ Debreceni Egyetem, Gazdaságtudományi Kar, Vidékfejlesztés, Turizmus-és Sportmenedzsment Intézet \\ Sportgazdasági- és Menedzsment Tanszék, koroknayzs@gmail.com \\ 2Debreceni Egyetem, Gazdaságtudományi Kar, Vidékfejlesztés, Turizmus-és Sportmenedzsment Intézet \\ Sportgazdasági- és Menedzsment Tanszék, pfau.christa@econ.unideb.hu
}

Absztrakt. A mai rohanó világban egyre nagyobb figyelmet kap az egészséges életmód, egészségünk megtartása, köszönhetően a feltörekvő egészségtrendeknek. A szakirodalmi áttekintés az egészséges magatartás két aspektusával foglalkozó kutatások legfrissebb eredményeit összesíti. Primer kutatásunkban a Debreceni Egyetem Gazdaságtudományi Kar sportszakos hallgatóinak sportolási és táplálkozási szokásait mértük fel. Sportolási szokások esetében a sportolás gyakoriságáról és motivációjáról kérdeztük meg a hallgatókat, míg táplálkozási szokásaik esetében a zöldség-, gyümölcs- és folyadékfogyasztás gyakoriságáról és mennyiségéről. A kérdőives megkérdezés kiértékelését követően elmondható, hogy a válaszadók $70 \%$ elégedett saját fizikai állapotával. A zöldség- és gyümölcsfogyasztás gyakoriságáról elmondható, hogy a vizsgálatban résztvevő hallgatók 15-20\%-ára igaz, hogy naponta fogyaszt zöldséget és/vagy gyümölcsöt. A hallgatók folyadékbeviteléról azonban pozitív képet láthatunk, hiszen hetvenhat százalékuk az ajánlásoknak megfelelő vagy annál nagyobb mennyiségü folyadékot fogyaszt naponta.

Abstract. Nowadays the healthy lifestyle is getting more and more attention, thanks to emerging health trends. The review of the literature summarizes the latest results of research on two aspects of healthy behavior. In our primary research, we measured the sporting and dietry habits of sport sciences' students at University of Debrecen. In the case of sporting habits, we asked the students about the frequency and motivation of sports. In the other hand we asked them about their dietary habits about the frequency and amount of vegetable, fruit and fluid consumption. After the evaluation of survey we can say that the $70 \%$ of respondents are satisfied with their physical condition. We can tell about the frequency of vegetable and fruit consumption is that the 15-20\% of students eat vegetables and / or fruits daily. However, it can be said about the fluid intake of students that seventysix percent of them are consuming fluid daily. 


\section{Bevezetés}

A mai rohanó világban egyre nagyobb figyelmet kap az egészséges életmód, egészségünk megtartása, köszönhetően a feltörekvő egészségtrendeknek. Az egészségtudatos magatartás vizsgálata összetett folyamat, hiszen több alkotóelemből álló dologról van szó, így teljeskörű vizsgálata nehezen kivitelezhető. Jelen kutatás során két komponens került vizsgálatra, azaz a testmozgás, sportolás, illetve az egészséges táplálkozás. Az egészségtudatos magatartás vizsgálatról szóló kutatások az utóbbi időben sokasodtak a felsőoktatási intézményekben tanuló fiatal felnőttekre vonatkozóan. A tanulmányban a Debreceni Egyetem Gazdaságtudományi Kar hallgatóinak egészségtudatos magatartásával kapcsolatos eredményeit ismertetjük, a sportolásra és egészséges táplálkozásra fókuszálva.

\section{Szakirodalmi áttekintés}

\subsection{Egészségtudatos magatartás}

Az egészségmagatartás klasszikus definíciója szerint [36] minden olyan tevékenységet értünk ez alatt, ami arra irányul, hogy megelőzzük a megbetegedéseket, valamint fenntartsuk egészséges állapotunkat. Az Állami Egészségügyi Ellátó Központ által létrehozott Egészségtudományi Fogalomtárban a következőképpen került meghatározásra: „(...) az egészségtudatos magatartás az egyén szemléletének, viselkedésének, tevékenységének összessége annak érdekében, hogy minél tovább és minél egészségesebb maradhasson." [I1]

Egy másik megközelítésben [23] „Az egészségmagatartás az emberi életvitel egy sajátos megnyilvánulása". Egy olyan magatartásról van szó - amit az egyén szokásai, tudása, készségei, értékei is befolyásolnak - amely az egészség érdekében tudatos megóvás, fenntartás és fejlesztés céljából történik [19][21]. Fodor (2013) szerint tehát az egészségmagatartásnak protektív (védelmező és fenntartó - ide tartozik az egészséges táplálkozás, mozgás), preventív (megelőző), illetve kockázati, patogén (betegséget okozó) magatartási típusai vannak.

Kutatásom során az egészségmagatartás alatt azt értem, hogy az egyének életvitelük során mit tesznek az egészség tudatos megóvása, fenntartása és fejlesztése céljából.

$\mathrm{Az}$ egészségtudatos magatartásnak elemei a nemzetközi és hazai szakirodalmakban a legelfogadottabbak Harris és Guten (1979) és Urbán (2001) közlései. Mindkét megállapításban nyolc elem került meghatározásra, közel azonos megnevezésekkel [21][41]. Az egészségtudatos magatartás elemei közzé tartozik többek között: káros szenvedélyektől való mentesség, egészséges, mértékletes táplálkozás, rendszeres testmozgás, lelki egészségről való gondoskodás, nyugodt élet, stresszkerülés, egészséges szexualitás, szűrővizsgálatokon való rendszeres megjelenés, védőoltások, táplálékkiegészítők, vitaminok fogyasztása, betegségek kezelése [20]. Ezen elemek közül a kutatás során az egészséges táplálkozást, valamint a rendszeres testmozgás került vizsgálat alá a Debreceni Egyetem hallgatói körében. 


\subsubsection{Fizikai aktivitás, sportolási szokások}

A legáltalánosabban elfogadott meghatározás a sportra az Európai Sport Chartaban megfogalmazottak. Azaz „minden olyan fizikai tevékenység, amely esetenként vagy szervezett formában a fizikai és szellemi erônlét fejlesztését szolgálja, társadalmi kapcsolatok teremtése vagy különböző szintü versenyeken elérendő eredmények céljából" [11]. Mivel a sport egy interdiszciplináris tudományterület, így csoportosításokat különböző megközelítések alapján alakíthatunk ki. Az előbbiek végett került a jogi csoportosításra a választás, hiszen ez törvényben meghatározott - mindenki által elfogadott csoportosítási nézet. A jelenleg hatályban lévő sporttörvény alapján megkülönböztetünk versenysportot, utánpótlásnevelést, diák- és főiskolai-egyetemi sportot, fogyatékosok sportját, valamint szabadidősportot [1].

A sport fontosságát jelzi, hogy számos hazai és nemzetközi kutató foglalkozott a témával, és annak fontosságával [2][6][7][13][14][15][16][18][22][25][33][34]. A kutatások java része a sportolás vagy nem sportolás egészségre gyakorolt hatásával, vagy annak gazdasági vonulatával foglalkoznak. Kutatások bizonyították, hogy kimutatható előnyei vannak a rendszeres fizikai tevékenységnek, valamint azt is, hogy megtakarítást jelent a fizikai inaktivitás csökkentése [33].

A fizikai aktivitás mérése az európai közösség számára is igen fontos, így négy évente felmérik a sport és fizikai aktivitási állapotot a közösségben (Eurobarometer) [37][38]. A felmérés adatai összességében és ország szerint is megtalálható. A felmérés során az aktív sporttevékenységet megkülönböztették az egyéb fizikai tevékenységtől, ahová a kerékpározás (mint közlekedési eszköz használata), tánc, kertészkedés is besorolásra került. A kutatás során ezen megkülönböztetési nézetekkel mi is egyetértettünk. Ezek alapján elmondható, hogy a fizikai aktivitásnak jelen kutatás során a sportolási tevékenységet értjük, így az egyéb fizikai tevékenységektől eltekintünk.

Így következőkben a magyar állapotot mutatjuk be a 2014-ben és 2018-ban megjelent eredmények alapján a két vizsgált területen.

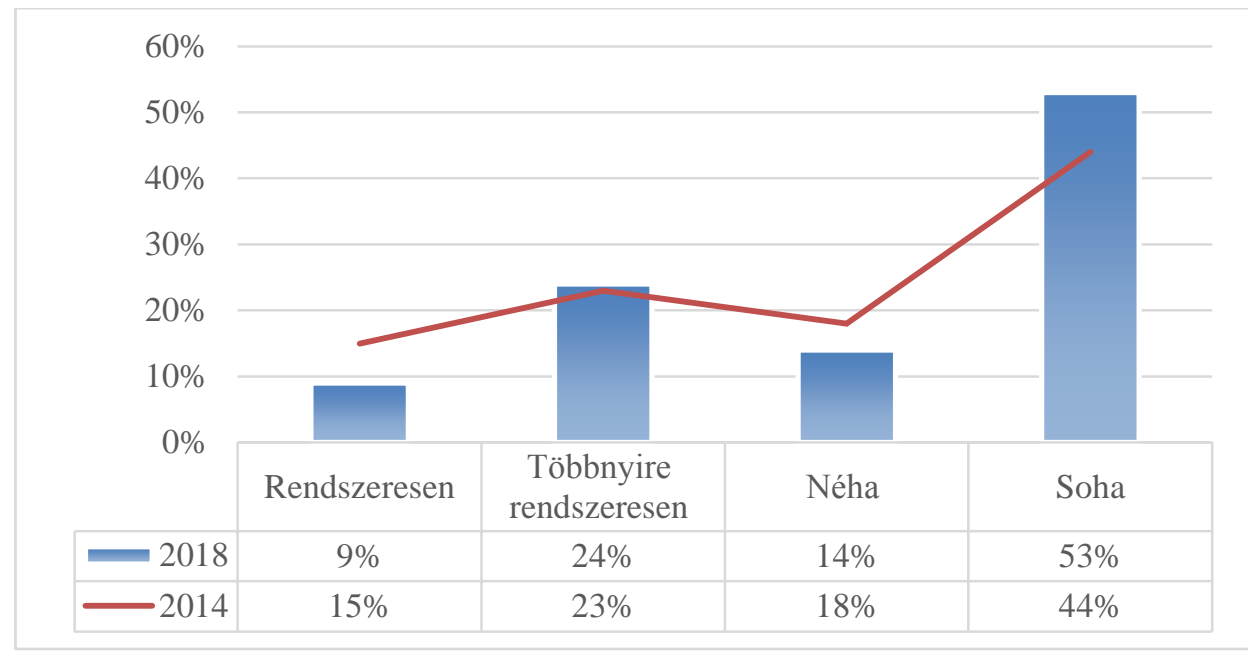

1. ábra: Sportolás gyakorisága

Forrás: Saját szerkesztés [37][38] alapján, 2019

A 1. ábra megmutatja, hogy 2014-ben és 2018-ban milyen válaszokat adtak a megkérdezettek arra a kérdésre, hogy milyen gyakran végeznek sportolási tevékenységet. Az ábra jól mutatja, hogy a 
legutóbbi mérés óta csökkent a rendszeresen vagy többnyire rendszeresen testmozgást végzők aránya azokhoz képest, akik 3 alkalommal havonta vagy annál kevesebbszer (néha), esetleg soha nem végeznek semmilyen sportolási tevékenységet.

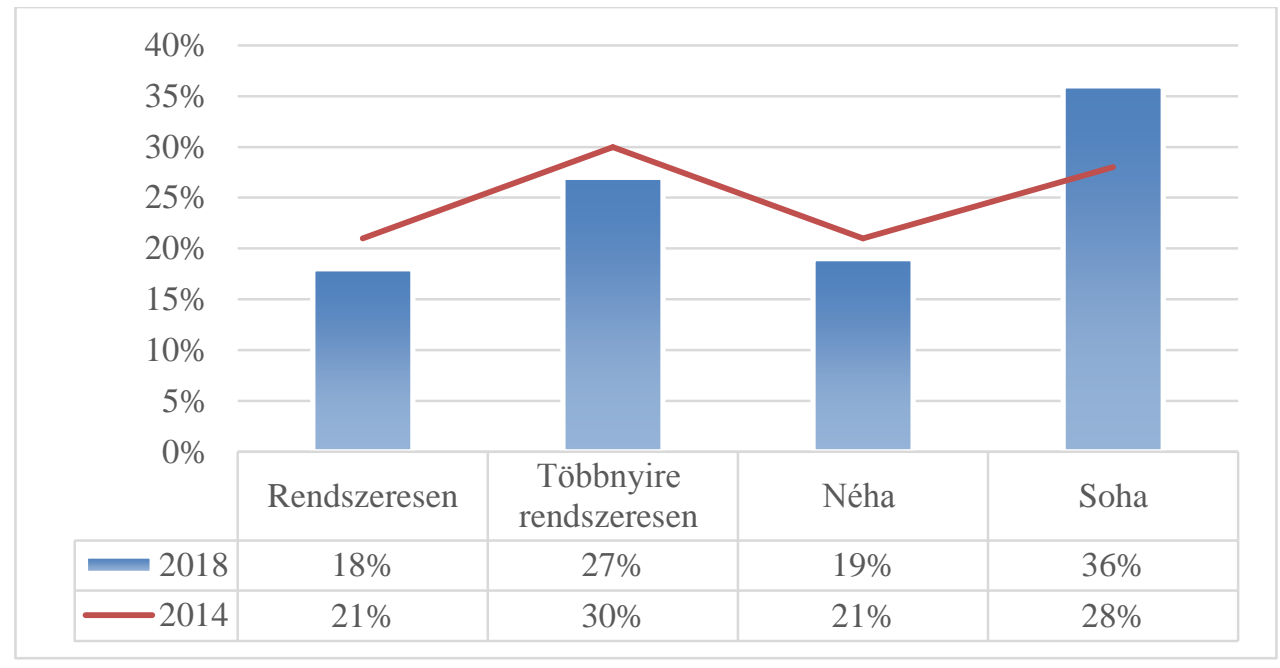

2. ábra: Egyéb fizikai tevékenységek gyakorisága

Forrás: Saját szerkesztés [37][38] alapján, 2019

A 2. ábra megmutatja, hogyha minden fizikai tevékenységet figyelembe veszünk - amelyeket már korábban említettünk - akkor már kedvezőbb képet kapunk (1. ábra 2. ábraához képest), de továbbra is elmaradunk az európai átlagtól. A 2014-es adatokhoz képest, a 2018-as adatok csökkenést mutatnak a rendszeres, vagy többnyire rendszeres fizikai aktivitás tekintetében, és 8\%-os növekedést azon válaszadók esetében, akik soha nem végeznek fizikai tevékenységet.

Ezen két ábra alapján elmondható, hogy a magyar lakosság egyre inkább fizikailag inaktív életet él, és folyamatosan csökken a rendszeresen sportolók vagy egyéb fizikai tevékenységet végzők száma. Ezen megállapítások egybeesnek a korábban felsorolt és áttekintett szakirodalmi forrásokkal.

\subsubsection{Egészséges táplálkozás}

Az egészséges táplálkozás magában foglalja a különböző élelmiszereket és folyadékokat, amelyeket megfelelő arányban, mennyiségben, minőségben és változatosan szükséges fogyasztanunk. Az egészséges táplálkozás fontos összetevői a friss és természetes ételek, gyümölcs és zöldség, vitaminokban és ásványi anyagokban gazdag ételek [4]. Mindez hozzájárul egészségünk megőrzéséhez és segít az jó közérzet kialakításában [26]. Ennek érdekében amerikai és európai ajánlásokat is találunk, amelyek segítenek a tájékozódásban, és kiváló útmutatóként szolgálnak [8][39].

Az amerikai ajánlás [8] kalória szintek szerint határozott meg étkezési mintákat. Az ajánlásban napi mennyiségeket találunk minden csoportra vonatkoztatva, valamint az egyes csoportokon belül az alkategóriákhoz kapcsolódó fogyasztási egységek is számszerűsítve lettek. Az ajánlás alapján elmondhatjuk, hogy az egészséges étkezés alapkövei a zöldség, gyümölcs, gabonafélék, tejtermékek, fehérjetartalmú élelmiszerek és olajok [8]. Mennyiségi ajánlás összességében a 400 grammnak megfelelő zöldség- és gyümölcsfogyasztás (vagy 5 darab) az, ami megfelelőnek mondható napi szinten. A 400 grammból 250 gramm zöldség és 150 gramm gyümölcs fogyasztási arány ajánlott. 
A legújabb európai ajánlásban szintén megtalálható a 400 grammos vagy 5 darabos zöldség- és gyümölcsfogyasztási kitétel (ami nem tartalmazza a burgonya, édesburgonya, manióka és más gumós növényeket) [12]. Az ajánlásban megtalálhatjuk azt is, hogy napi energiabevitel kevesebb mint 10\%-át (ideálisabb esetben kevesebb mint 5\%-át) kell biztosítani cukrokból, ami körülbelül 50 grammnak felel meg. Az energiabevitel kevesebb mint 30\%-át szükséges zsírokból, azt is lehetőleg telítetlen zsírsavakból fedezni. Továbbá fontos, hogy a napi sófogyasztás ne haladja meg az 5 grammot [I2].

A kétezres éveket követően számos kutatás foglalkozik a táplálkozás fontosságával [41][35][42][27][3]. Ezen kutatásokban nemcsak az „átlag” emberek, hanem a sportolók esetében is kiemeleten hangsúlyozzák az egészséges és tudatos táplálkozás fontosságát. Több cikkben is látható az amerikai és európai ajánlásban talált napi 400 grammos gyümölcs- és zöldségfogyasztást, ami alapján elmondható, hogy mind nemzetközi, mind hazai szintéren is elfogadott mennyiségű zöldség- és gyümölcsbevitelről van szó.

$\mathrm{Az}$ egészségvesztés legfóbb okait alapvetően három csoportba sorolhatjuk: viselkedés okozta kockázatok (dohányzás, stressz, inaktivitás, nem megfelelő minőségű és mennyiségi táplálkozás), élettani kockázatok (születéskori vagy öröklött betegségek), illetve környezeti kockázatok (szélsőséges időjárás, balesetveszélyes sportinfrastruktúra) [17]. Ezen egészségvesztési okok különkülön, vagy kombinálva is megjelenhetnek.

A magyar lakosságra nézve mindez a 2016-os évben azt jelenti, hogy az egészségveszteség 35,2\%-át a viselkedési kockázatok, 29,6\%-át a viselkedési és az élettani kockázatok együttesen, 19\%-át az élettani kockázatok, 3,4\%-át a környezeti kockázatok, és 6-6\%-át a viselkedési és környezeti kockázatok együtt, illetve mindhárom kockázati tényező együtt okozza [17]. A további egészségveszteséget okozó tényezők között megtalálható a magas vérnyomás, dohányzás, túlzott alkoholfogyasztás, magas koleszterin- és vércukorszint, magas sófogyasztás, vagy éppen az alacsony gyümölcsfogyasztás [17]. Ezen veszélyeztető tényezők közül a sófogyasztás és az elhízás a következőképpen alakul Magyarországon. A legújabb OECD jelentés alapján [30] elmondható, hogy a magyarok nem megfelelő minőségű és mennyiségű táplálkozásból adódóam az elhízás vagy túlsúly a felnőtt lakosság több mint kétharmada érinti. Az elhízás mutató rangsorában az 5. helyen állunk sorrendben az USA, Chile, Mexikó és Új-Zéland után [30]. Az OTÁP legutóbbi felmérésében [31][32] látható, hogy az egészséges és ajánlott napi 5 gramm sófogyasztást a magyar átlagos értékek jóval meghaladták. A felmérés szerint a nők esetében napi 11 gramm, a férfiak esetében napi 16 gramm átlagosan, ami több mint kétszerese vagy háromszorosa az ajánlásnak. Ugyanezen felmérésben szintén találunk további adatokat az elhízás gyakoriságára (3. ábra), ami a nőknél átlagosan 60\% körül, míg a férfiak esetében 65\% körül alakul, ám megfigyelhető, hogy ez az arány növekvő tendenciát mutat a kor előrehaladtával [31][32].

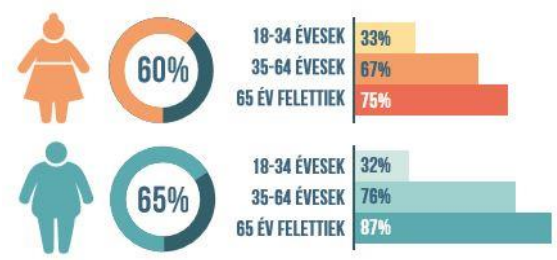

3. ábra: A magyar lakosság túlsúly és elhízási gyakorisága Forrás: [32] 
A NEFI Egészségjelentései alapján elmondható, hogy a felnőtt magyar lakosság közel fele munkája során nem végez fizikai aktivitást, és a magyar lakosság 66\%-a szabadidejében sem sportol legalább napi 10 percet [28]. 2014-ben a felnőtt lakosság közel kétharmada fogyasztott naponta valamilyen gyümölcsöt vagy zöldséget, és az életkor előrehaladásával ez egyre nagyobb arányban figyelhető meg. Ám a táplálkozás során bevitt tápanyagok aránya eltér a hazai és nemzetközi ajánlásoktól. A vitamin és ásványianyagfogyasztás kritikusan alacsony volt, míg a sóbevitel jelentősen meghaladta az ajánlott mennyiséget. „Az állati eredetű zsiradékok, a húsok, húskészítmények rendszeres és túlzott fogyasztása, a zöldségek, gyümölcsök, a tej és tejtermékek, valamint a gabonafélék igen alacsony fogyasztása jellemzi a felnôttek táplálkozását."[29] Az Országos Táplálkozás és Tápláltsági Állapot Vizsgálat (2014) eredményei megmutatták, hogy a nők 65\%-a, férfiak 68\%-a, az ajánlott napi 400 gramm zöldséggyümölcsnél kevesebbet fogyaszt [31].

Az élelmiszerfogyasztás mellett a folyadékfogyasztás is része az egészséges táplálkoznak. Az egyik legrészletesebb ajánlás Jéquier - Constant (2010) műben található, amely alapján a következő táblázat (1. táblázat) összefoglalja nem és kor szerint az ajánlott napi folyadékbevitelt. Ám itt szükséges megjegyezni, hogy az amerikai ajánlásokban a zöldségléből származó folyadékbevitel is az ajánlott összfolyadék mennyiségbe tartozik ugyanazon napi ajánlások mellett.

\begin{tabular}{ccccccc}
\hline & \multicolumn{2}{c}{$\begin{array}{c}\text { Ajánlott folyadékfogyasztás férfiaknál } \\
\text { (ml/nap) }\end{array}$} & \multicolumn{3}{c}{ Ajánlott folyadékfogyasztás nöknél } \\
Életszakasz & \multicolumn{3}{c}{ (map) } \\
\cline { 2 - 7 } & Gyümölcsből & Italból & $\begin{array}{c}\text { Összes } \\
\text { folyadék }\end{array}$ & Gyümölcsből & Italból & $\begin{array}{c}\text { Összes } \\
\text { folyadék }\end{array}$ \\
\hline $\mathbf{2 - 3}$ éves & 390 & 910 & 1300 & 390 & 910 & 1300 \\
\hline $\mathbf{4 - 8}$ éves & 480 & 1120 & 1600 & 480 & 1120 & 1600 \\
\hline $\begin{array}{c}\text { 9-13 éves } \\
\text { 14 évnél } \\
\text { több }\end{array}$ & 630 & 1470 & 2100 & 570 & 1330 & 1900 \\
\hline $\begin{array}{c}\text { Terhesség } \\
\text { Szoptatás }\end{array}$ & 1750 & 2500 & 600 & 1400 & 2000 \\
\hline & & & 690 & 1610 & 2300 \\
\hline
\end{tabular}

\section{1. táblázat: Ajánlott folyadékbevitel nem és korcsoport szerint}

Forrás: Saját szerkesztés [9] alapján, 2019

A folyadékbevitel a nemek közötti megoszlásban látható életszakaszokra bontva. Mindkét nem esetében 8 éves korig azonos az ajánlás, majd ezt követően válik ketté. A felnőtt férfiak ajánlása 2,5 liter folyadék, míg a nőknek 2 liter (terhesség és szoptatás ideje alatt ez megemelkedik 2,3 és 2,7 literre).

Mindezek alapján elmondható, hogy Magyarországon három felnőttből kettő túlsúlyos vagy elhízott [32]. A felnőtt lakosság közel kétharmada fogyaszt naponta valamilyen gyümölcsöt vagy zöldséget, de 
ez nem haladja meg az ajánlott 400 grammot. Folyadékfogyasztás esetében pedig a nők esetében 2 liter, míg a férfiak esetében 2,5 liter folyadék ajánlott (gyümölcsből és italból összesen).

\section{Anyag és módszer}

Vizsgálatunk során primer és szekunder adatelemzést végeztünk. Szekunder vizsgálat során elemeztük a hazai és nemzetközi irodalomban fellelhető releváns tanulmányokat és cikkeket. Primer kutatásunk során kérdőíves megkérdezést hajtottunk végre a Debreceni Egyetem hallgatói körében. A téma vizsgálatához a meghatározott kérdéseket három csoportba osztottuk: a hallgatók demográfiai jellemzői, a hallgatók táplálkozási szokásai, valamint a hallgatóság sportolásai szokásai. Megkérdezés során törekedtünk arra, hogy a nappali tagozatos, sporttudományokat hallgatók mindhárom évfolyama bekerüljön a mintába. A minta kialakítása során célunk volt a sporttudományokat hallgatók szinte teljes körű felmérése, nemcsak az alapszakos Sportszervező, illetve Sport- és Rekreációszervező hallgatók körében, hanem a mesterszakos Sportközgazdász hallgatók körében is.

Az adatokat a 2018/19. tanév I. félévében gyüjtöttük össze, aminek keretében 266 kérdőív került kitöltésre a hallgatóság által, melyből 129 fő sporttudományokat hallgató személy.

A kérdőíves megkérdezés papír alapon történt, hiszen ezen módszer segítségével olyan hallgatókat is sikerült elérni, akik nem végeznek sem szabadidős-, sem versenysport tevékenységet. Az adatokat közvetlenül az IBM SPSS Statistics 22 programban vittük fel úgy, hogy minden egyes kérdés válaszát kódoltuk, annak érdekében, hogy megkönnyítsük a későbbi statisztikai vizsgálatok elvégzését. A felmérés 11 zárt kérdésből állt. A zárt kérdések esetében a válaszadók az általunk megadott válaszlehetőségek közül jelölhették meg a számukra igaz, legjellemzőbb vagy leginkább egyetértő feltevéseket.

A kérdőív kitöltése önkéntes és anonim módon történt. A kérdőíves megkérdezésben a nappali tagozatos hallgatók vettek részt. A lekérdezés három hónap alatt zajlott le a Debreceni Egyetem Böszörményúti Campusán. A kérdőívek kitöltése a campuson tartott testnevelési órákon zajlott (a Debreceni Egyetem Sporttudományi Koordinációs Intézet igazgatójának engedélyével) a testnevelők és edzők segítségével; kiemelve azt, hogy a kérdések megválaszolásakor a testnevelés órán való részvétel nem számít szabadidősport-tevékenységnek. A kitöltök nem szerinti megoszlása a 4. ábra mutatja.

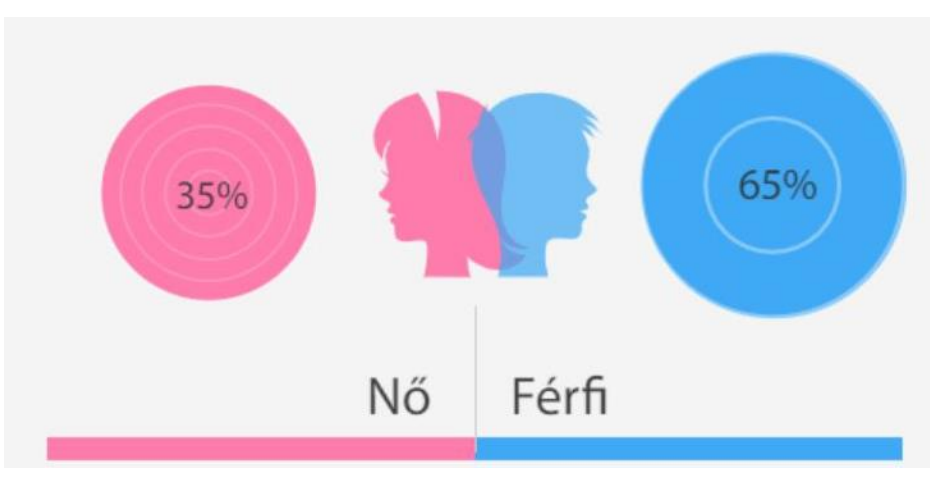

4. ábra: Válaszadók nem szerinti megoszlása ( $n=129)$

Forrás: Saját szerkesztés, 2019 
A felmért hallgatók megoszlásáról - települési helyüket tekintve - elmondható, hogy 86,7\% megyei jogú városban vagy városban van az állandó lakhelye, míg 13,2\%-uk község, falu vagy tanya településtípusból származik.

Életkorukat tekintve széles skála figyelhető meg. A vizsgálati mintában résztvevők születési éve 1976 és 2000 között oszlik meg. A 27 és 43 év közötti hallgatók a vizsgálati minta 3,9\%-át, a 23 és 26 év közötti hallgatók a 20\%-át, míg a 19 és 22 év közötti korosztály a 76,1\%-át teszi ki.

A Hiba! A hivatkozási forrás nem található. megmutatja, hogy a vizsgálati mintában résztvevők szak és évfolyam szerinti megoszlása hogyan alakult. Látható, hogy az alapszakos hallgatók mindegyik évfolyamát sikerült felmérni (a szak névváltozásából adódik a BSc-s hallgatók másod és harmadévfolyama külön soron szerepelnek). A mester szakos hallgatók esetében pedig a másodévfolyam került felmérésre.

\begin{tabular}{|c|c|c|c|c|}
\hline \multirow{2}{*}{ Szak } & \multicolumn{3}{|c|}{ Évfolyam } & \multirow{2}{*}{ Összesen } \\
\hline & 1 & 2 & 3 & \\
\hline Sport- és rekreációszervező & 72 & 22 & 0 & 94 \\
\hline Sportszervező & 0 & 0 & 28 & 28 \\
\hline Sportközgazdász & 0 & 7 & 0 & 7 \\
\hline Összesen & 72 & 29 & 28 & 129 \\
\hline
\end{tabular}

2. táblázat: A vizsgálati minta szak és évfolyam szerinti megoszlása

Forrás: Saját szerkesztés, 2019

A kérdőívben feltett kérdések kiértékelése során az alapstatisztikai mutatók mellett kereszttáblás vizsgálatokat hajtottunk végre. Az SPSS Explore parancs után kapott mutatók közül az alapstatisztikai mutatókat vizsgáltuk meg, azaz az átlagot, vágott átlagot, szórást, minimum és maximum értékeket, valamint módusz és medián mutatókat. A kereszttáblás vizsgálat két nem paraméteres változó közötti összefüggést vizsgálja úgy, hogy a két változó értékeinek kombinációját mutatja be táblázatos formában [24].

\section{Eredmények}

A kérdőíves megkérdezés során kíváncsiak voltunk a válaszadók önbevallásos megelégedettségére saját fizikai állapotukra vonatkozóan, amit egy hét fokozatú skála segítségével mértünk fel. (5. ábra). Legnagyobb százalékban a 5-6 skála érték volt a válasz, valamint ehhez hozzákapcsolva a 7 fokot elmondható, hogy a válaszadók 70\% elégedett saját fizikai állapotával. Pfau (2017) kutatási eredményei szintén azt mutatják, hogy a felmért egyetemek megkérdezett hallgatóinak többsége elégedett saját fizikai állapotával [4]. 


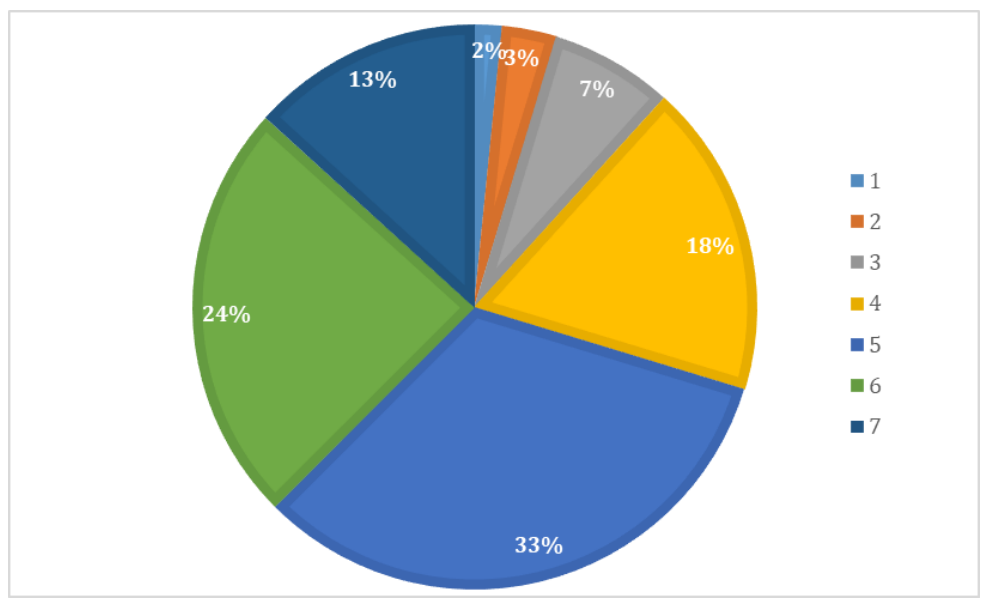

5. ábra: Válaszadók fizikai állapotával való megelégedettség

Forrás: Saját szerkesztés, 2019

A Hiba! A hivatkozási forrás nem található. bemutatja a sportszakos hallgatók sportolási szokásait rendszeresség és sportolási szintet figyelembevéve. Látható, hogy mindössze 4 hallgató nem végez semmilyen fizikai tevékenységet, valamint 9 hallgató sportol háromszor egy hónapban vagy kevesebbszer. A vizsgálati mintában 46-an versenyszerűen sportolnak, 76-an pedig szabadidejükben végeznek sportolási tevékenységet.

\begin{tabular}{|c|c|c|c|c|}
\hline \multirow[b]{2}{*}{$\begin{array}{l}\text { Ha igen, milyen } \\
\text { rendszeresen? }\end{array}$} & \multicolumn{3}{|c|}{ Jelenleg sportol? } & \multirow[b]{2}{*}{ Összesen } \\
\hline & Igen, versenyszerűen & $\begin{array}{l}\text { Igen, hobby szinten } \\
\text { Szabadidőmbe }\end{array}$ & Nem & \\
\hline Legalább ötször egy héten & 26 & 14 & 0 & 40 \\
\hline 1-4 alkalommal egy héten & 19 & 57 & 0 & 76 \\
\hline $\begin{array}{l}\text { Háromszor egy hónapban } \\
\text { vagy kevesebbszer }\end{array}$ & 1 & 5 & 3 & 9 \\
\hline Soha & 0 & 0 & 4 & 4 \\
\hline Összesen & 46 & 76 & 7 & 129 \\
\hline
\end{tabular}

3. táblázat: Kereszttáblás vizsgálat sportolással kapcsolatosan

Forrás: Saját szerkesztés, 2019

Kíváncsiak voltunk arra, hogy az egyetemi hallgatók milyen sportolási motivációval rendelkeznek. A 6. ábra szemlélteti a megkérdezettek válaszait. Az egyes válaszlehetőségekre adott egyetértési arány 3,0 - 3,65 között alakult. A válaszokból látható, hogy a sportolási motivációk között a legkevésbé meghatározó a győzelem, társaság, önbizalom, amelyek közel azonosak Pfau (2017) kutatási eredményeivel. A legmotiválóbb tényezők közé tartozik az egészség, az öröm, kikapcsolódás vagy jó közérzet. Ezen válaszok átlagainak alakulása alapján megfigyelhető a hallgatók sportolási individualizálódása, azaz az egyéni sportolási lehetőségek kerülnek előtérbe - a labdarúgáson mellett. Továbbá az egészség a legfőbb motiváló sportolási tényező, amelyből az feltételezhető, hogy a sportszakos hallgatók nagy egészségtudattal rendelkeznek, ami az egészséges magatartás egyik fő jellemzője. 


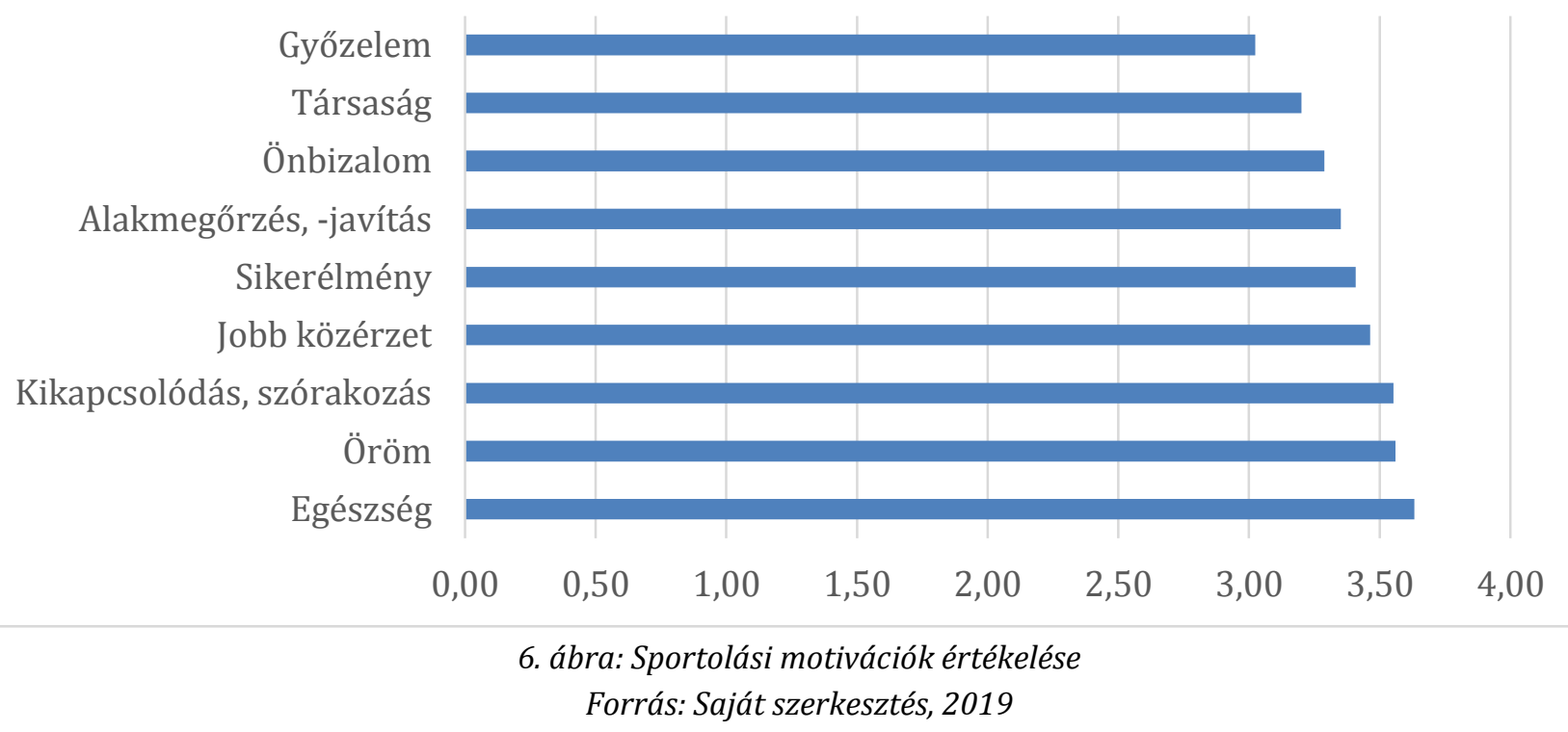

A kérdőíves megkérdezés során sportolással és táplálkozással kapcsolatos állításokat tettünk, amelyet egy négy fokozatú skálán értékeltek a sportszakos hallgatók, hogy mennyire értenek egyet vagy sem (Hiba! A hivatkozási forrás nem található.).

\begin{tabular}{|c|c|c|c|c|}
\hline Állítások & Átlag & Medián & Módusz & Szórás \\
\hline A sportolás hasznos tevékenység. & 3,91 & 4,00 & 4 & 0,307 \\
\hline $\begin{array}{l}\text { A megfelelő sportolás fontos egészségmegőrzésünk } \\
\text { szempontjából. }\end{array}$ & 3,88 & 4,00 & 4 & 0,355 \\
\hline Mindenki számára hasznos a testmozgás. & 3,74 & 4,00 & 4 & 0,520 \\
\hline $\begin{array}{l}\text { A sportolás helyettesíthető bármilyen más szabadidős } \\
\text { tevékenységgel. }\end{array}$ & 2,49 & 2,00 & 2 & 1,009 \\
\hline A sportolás nem fontos tevékenység. & 1,29 & 1,00 & 1 & 0,733 \\
\hline A sportolás inkább káros, mint hasznos. & 1,21 & 1,00 & 1 & 0,621 \\
\hline A sportolás sérülésveszélyes. & 2,46 & 2,00 & 2 & 0,901 \\
\hline A sportoláshoz pozitív élmények füződnek. & 3,55 & 4,00 & 4 & 0,599 \\
\hline Fontos tudatosan figyelni a gyümölcs- és zöldségbevitelre. & 3,39 & 3,00 & 4 & 0,699 \\
\hline Fontos, hogy naponta nyers gyümölcsöt együnk. & 3,14 & 3,00 & 3 & 0,737 \\
\hline Fontos, hogy naponta nyers zöldséget együnk. & 3,10 & 3,00 & 3 & 0,759 \\
\hline Fontos odafigyelni az egészséges táplálkozásra. & 3,65 & 4,00 & 4 & 0,542 \\
\hline $\begin{array}{l}\text { Rendszerint szezonális gyümölcsöt/zöldséget vásárolok. (pl: } \\
\text { dinnye augusztusban) }\end{array}$ & 3,09 & 3,00 & 4 & 0,905 \\
\hline $\begin{array}{l}\text { A túlzott gyümölcs- vagy zöldségbevitelnek káros hatásai } \\
\text { lehetnek. }\end{array}$ & 1,98 & 2,00 & 1 & 0,914 \\
\hline $\begin{array}{l}\text { Azokat az ételeket preferálom, amelyek hozzájárulnak az } \\
\text { egészségmegőrzéshez. }\end{array}$ & 3,04 & 3,00 & 3 & 0,795 \\
\hline $\begin{array}{l}\text { Az egészséges táplálkozás fontosabb, mint a fizikai } \\
\text { aktivitás/mozgás. }\end{array}$ & 2,39 & 2,00 & 2 & 0,813 \\
\hline
\end{tabular}

4. táblázat: Sportolási és táplálkozási szokásokkal kapcsolatos állitások értékelése Forrás: Saját szerkesztés, 2019

Az első három tétel, melyben a sport pozitív oldalról került megközelítésre szinte teljes mértékben az egyetértő skálaérték került választásra. Viszont abban az esetben, ha a sport helyettesíthetőségéről 
tettünk állítást, már összességében nem volt egyetértés a válaszadók körében. A sporttal kapcsolatos negatív állítások pedig egyértelműen a válaszadók egyet nem értését tükrözi.

Az egészséges táplálkozáshoz kapcsolódó állítások esetében szintén megfigyelhető a pozitív oldalról való megközelítéssel való szinte teljes mértékben való egyetértés. Ám az egészséges táplálkozást negatív megközelítésben való feltüntetéssel nem értettek egyet a válaszadók.

$\mathrm{Az}$ állításokra adott válaszok alapján összességében elmondható, hogy a sportolás hasznos tevékenység, melynek sokoldalú, pozitív hatásai vannak mind a testre, mind a lélekre a válaszadók alapján. Mindemellett az inkább egyetértenek azzal, hogy fontos a megfelelő mennyiségű zöldség és gyümölcsfogyasztás.

A vizsgálati mintában résztvevő sportszakos hallgatók zöldség és gyümölcsfogyasztási szokásait a Hiba! A hivatkozási forrás nem található. mutatja be. A válaszadók mindössze 28\%-a (36 fő) fogyaszt a napi ajánlásnak megfelelő mennyiségű zöldséget/gyümölcsöt, amely véleménye szerint is elegendő. További 5 fő az, aki szintén a napi fogyasztást betartja, ám azt a mennyiséget nem gondolja elegendőnek. A megkérdezett sportszakos hallgatók 38,3\%-a gondolja úgy, hogy nem fogyaszt elegendő mennyiséget, ami helytálló, hiszen a napi ajánlott fogyasztott mennyiséget sem viszi be a szervezetébe.

\begin{tabular}{|c|c|c|c|}
\hline \multirow{2}{*}{$\begin{array}{l}\text { Véleménye szerint fogyaszt } \\
\text { elegendő zöldséget/gyümölcsöt? }\end{array}$} & \multicolumn{2}{|c|}{$\begin{array}{l}\text { Naponta fogyaszt legalább } 5 \text { darabot } \\
(400 \mathrm{~g}) ?\end{array}$} & \multirow[t]{2}{*}{ Összesen } \\
\hline & Igen & Nem & \\
\hline Igen & 36 & 38 & 74 \\
\hline Nem & 5 & 49 & 54 \\
\hline Összesen & 41 & 87 & 128 \\
\hline
\end{tabular}

5. táblázat: Kereszttáblás vizsgálat a zöldség és gyümölcsfogyasztásról

Forrás: Saját szerkesztés, 2019

A kereszttáblában vizsgált két változó közötti összefüggés vizsgálatát a khi $^{2}$ próba segítségével hajtottuk végre. Pearson-féle khi² $^{2}$, Likelihood Ratio, Fisher's Exact Test, valamint Linear-by-Linear Association teszt szignifikancia szintje $0,00(\mathrm{p}=0,05)$, ami azt jelenti, hogy a nullhipotézis elvetésre került, tehát a két változó függőségi kapcsolat áll fent. A szimmetrikus mutatók eredményei alapján ez a függőségi kapcsolat gyenge, ugyanis a Phi, Chramer V és kontingencia-együttható is 0,4 körüli érték mentén mozog.

A válaszadók gyümölcs és zöldségfogyasztási szokásait a 7. ábra szemléleti. 


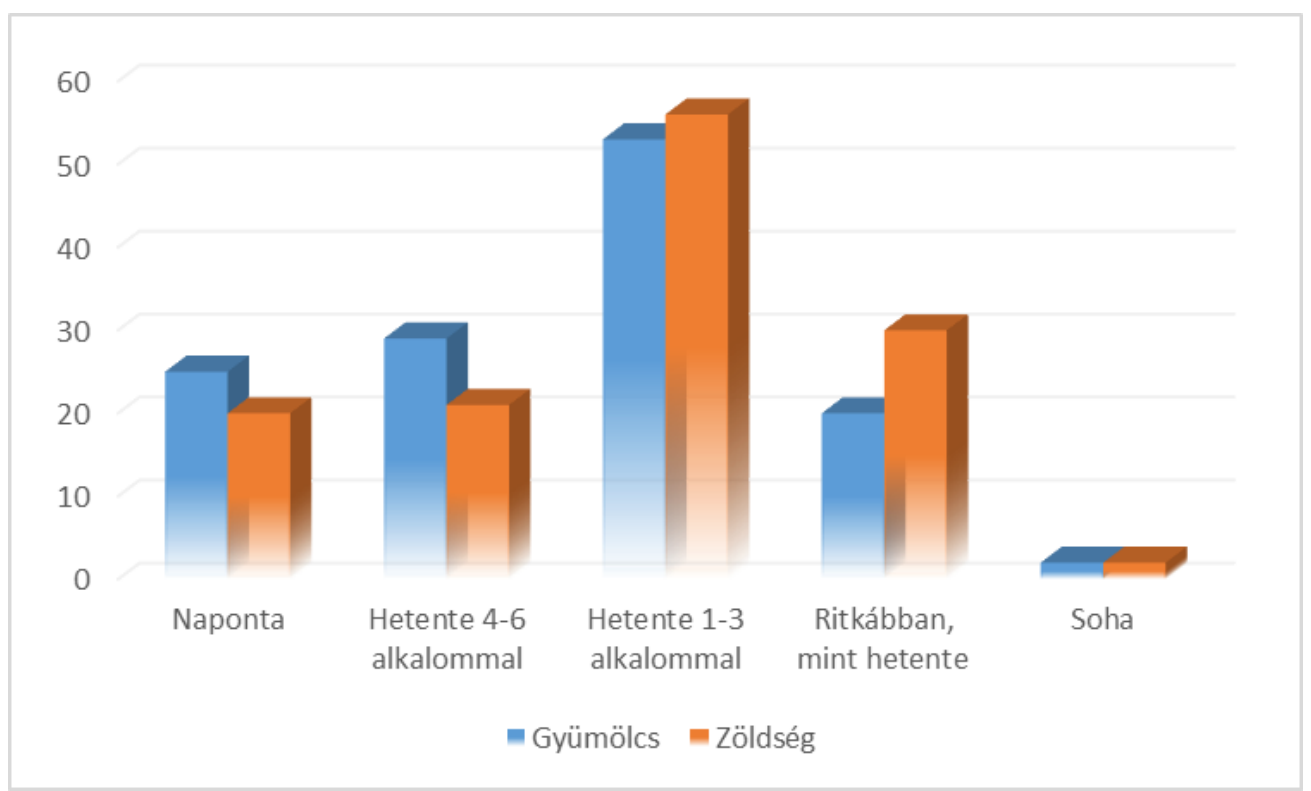

7. ábra: Zöldség és gyümölcsfogyasztás gyakorisága

Forrás: Saját szerkesztés, 2019

Az ábra alapján elmondható, hogy a gyümölcsfogyasztásban többen tudatosabbak, mint zöldségfogyasztásban, hiszen többségben vannak a naponta és heti 4-6 alkalommal gyümölcsöt fogyasztók (válaszadók 41,9\%-a). Zöldségfogyasztás esetében ez csak 31,8\%, ami kedvezőtlen az ajánlott fogyasztási mennyiséghez viszonyítva. Azok a hallgatók, akik ritkábban, mint hetente vagy soha válaszlehetőséget jelölték 20-30 főt tesznek ki. Mindezek alapján elmondható, hogy a nemzetközi és hazai ajánlásoknak a válaszadók mindössze 15-20\%-a képes eleget tenni.

A gyümölcs- és zöldségfogyasztás mellett a folyadékfogyasztást, mint egészségtudatos táplálkozási elemet is megvizsgáltuk. A 8 . ábra bemutatja, hogy a vizsgálati mintában résztvevők mindössze 24\%-a nem fogyaszt az ajánlásoknak megfelelő mennyiségű folyadékot.

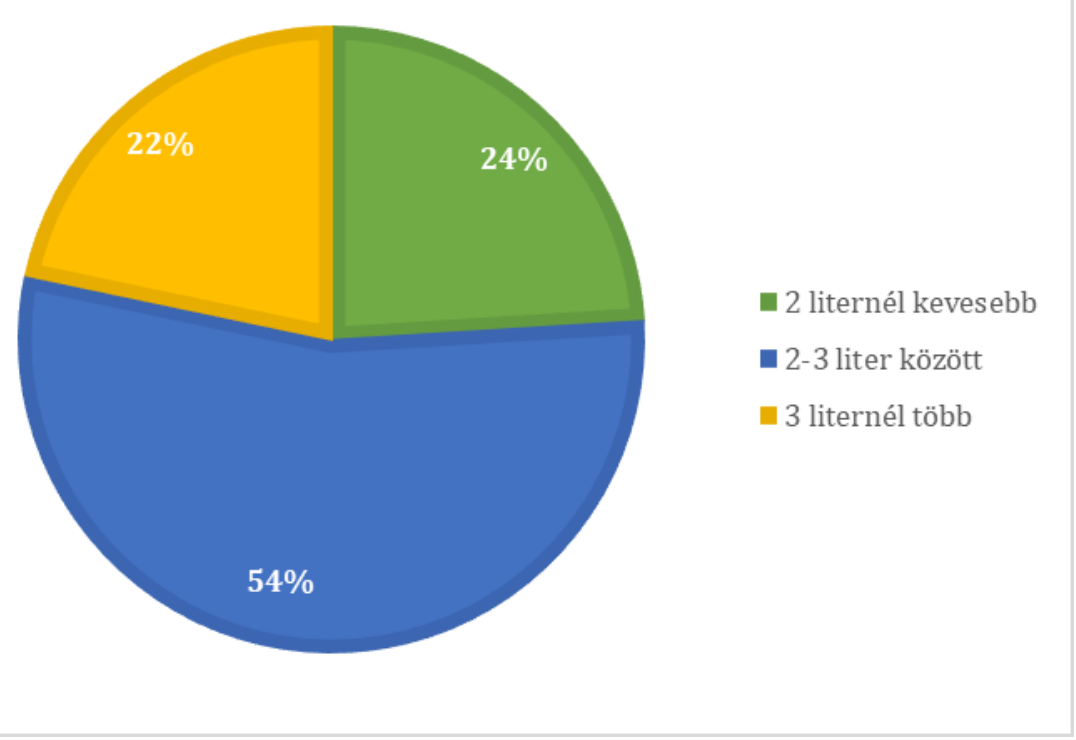

8. ábra: Folyadékfogyasztás alakulása

Forrás: Saját szerkesztés, 2019 
Ezek után megvizsgáltuk a két egészséges táplálkozási tényező közötti összefüggést kereszttáblás vizsgálat segítségével. A 6. táblázat szemlélteti a kapott eredményeket. Látható, hogy 31 fő nem fogyaszt elegendő mennyiségű folyadékot, ezen belül pedig a többségük nem fogyaszt elegendő zöldséget és gyümölcsöt önbevallás alapján. Hatvankilenc fő fogyaszt a nemzetközi és haza ajánlásoknak megfelelő mennyiségű folyadékok, és közülük 45-en elegendő zöldséget és gyümölcsöt is fogyaszt.

\begin{tabular}{|c|c|c|c|c|}
\hline \multirow{2}{*}{$\begin{array}{c}\text { Véleménye szerint fogyaszt } \\
\text { elegendő } \\
\text { zöldséget/gyümölcsöt? }\end{array}$} & \multicolumn{3}{|c|}{ Naponta átlagosan hány liter folyadékot fogyaszt? } & \multirow{2}{*}{ Összesen } \\
\hline & $\begin{array}{l}2 \text { liternél } \\
\text { kevesebb }\end{array}$ & 2-3 liter között & 3 liternél több & \\
\hline Igen & 12 & 45 & 17 & 74 \\
\hline Nem & 19 & 24 & 11 & 54 \\
\hline Összesen & 31 & 69 & 28 & 128 \\
\hline
\end{tabular}

6. táblázat: Folyadék és zöldség/gyümölcs közötti kereszttáblás vizsgálat

Forrás: Saját szerkesztés, 2019

A két változó közötti összefüggés a khi² próba alapján megállapítható, hogy függőségi viszonyban van, hiszen a szignifikanciaszint 0,043 (p=0,05). A szimmetrikus mutatók azonban 0,4 alatti értékeket mutat, tehát csak gyenge kapcsolat van a két folyadék és zöldség/gyümölcs fogyasztása között.

\section{Következtetések}

Vizsgálatunk során a Debreceni Egyetem Gazdaságtudományi Karán sporttudományokat hallgató diákokat mértük fel egészségtudatos magatartásuk két aspektusból. A vizsgálati mintában szinte minden évfolyam nagy aránnyal képviseltette magát. A vizsgálat során a sportolási és táplálkozási szokásokra vonatkozóan tettünk fel kérdéseket, amire összesen 129 hallgató adott választ.

A kérdőíves megkérdezésekor a mintában résztvevő hallgatók többsége elégedett saját fizikai állapotával. Mindezt alátámasztja az is, hogy mindössze 4 hallgató nem végez semmilyen fizikai aktivitást, míg a többség versenyszerűen vagy szabadidejében heti 1-5 alkalommal végez sportolási tevékenységet. Sportolási motivációjuk esetében a legkiemelkedőbb az öröm, kikapcsolódás, sikerélmény vagy a jobb közérzet. A kérdőívben feltett állításokból - a sportolásra vonatkozóan megállapítható, hogy a sporttudományokat hallgatók teljesen egyetértenek azzal, hogy a sport egy hasznos tevékenység, melynek nemcsak a testre, hanem az egyén szellemére is pozitív hatással van.

Az egészségtudatos magatartás másik vizsgált aspektusa az egészséges táplálkozás volt. A válaszadók saját bevallásuk szerint megfelelő mennyiségű zöldséget és gyümölcsöt fogyasztanak, ám ez nincs összhangban a nemzetközi és hazai ajánlásoknak megfelelő mennyiséggel, így egy szűkebb keresztmetszetről mondható el, hogy mindkét megközelítés igaznak bizonyul. A zöldség- és gyümölcsfogyasztás gyakoriságáról elmondható, hogy a felmért hallgatók közül 20-25 főre igaz, hogy naponta fogyaszt zöldséget és/vagy gyümölcsöt. A hallgatók folyadékbeviteléről azonban pozitív képet láthatunk, hiszen hetvenhat százalékuk az ajánlásoknak megfelelő vagy nagyobb mennyiségű napi folyadékbevitellel rendelkezik. A két egészséges táplálkozási elem közötti kapcsolatról pedig megállapítottuk, hogy a két változó függ egymástól, ám csak gyenge kapcsolatról van. 
A kutatás rámutat arra, hogy a sporttudományokat hallgatók egészségtudatos magatartása kedvező, a sportolási szokásokat figyelembe véve, hiszen magas sportolási aktivitás figyelhető meg. Ám az egészséges táplálkozásra való tudatos figyelés még nem megfigyelhető, így ezen területre való fejlesztése és hangsúlyozása a hallgatók számára fontos célkitűzés lehet.

\section{Köszönetnyilvánítás}

„A publikáció elkészítését az EFOP-3.6.1-16-2016-00022 számú, Debrecen Venture Catapult Program című projekt támogatta. A projekt az Európai Unió támogatásával, az Európai Szociális Alap társfinanszírozásával valósult meg."

\section{Hivatkozások}

[1] 2004. évi I. törvény, Sporttörvény

[2] A. Kovács - D. Paár - Zs. Welker - D. Fürész - G. Elbert - M. Stocker - P. Ács (2016) Sportfogyasztási szokások alakulásának aktuális helyzete. Magyar Sporttudományi Szemle. 17 (68)

[3] A. S. Szabó (2013) Táplálkozásgenomika a sportban. Magyar Sporttudományi Szemle. 14 (53) pp. 40-44.

[4] C. Pfau (2017) A szabadidôsport szervezési sajátosságai a felsőoktatásban. Doktori (PhD) értekezés, Debrecen

[5] C. Pfau - A. Müller - Z. Bács - É. Bácsné Bába (2018) Az egészséges táplálkozás szerepe és jelentősége. Táplálkozásmarketing. (5) 1.

[6] C. Pfau - Z. Bács - V. Fenyves - É. Bácsné Bába (2018) Szabadidősport szolgáltatások értékelési lehetöségei - Felsőoktatási környezetbe adaptálva. International Journal of Engineering and Management Sciences. 3 (4)

[7] Cs. Konczos - Zs. Szakály (2007) Az ifjúság fizikai aktivitásának jellemzôi, az életstílus befolyásolása a fizikai aktvitás tudatos alkalmazása. Magyar Sporttudományi Szemle. 8 (2) pp. 39-46.

[8] Dietary Guidelines For Americans 2015-2020: https://health.gov/dietaryguidelines/2015/guidelines (Letöltés dátuma: 2018. 11. 08.)

[9] E. Jéquier - F. Constant (2010) Water as an essential nutrient: the physiological basis of hydration. European Journal of Clinical Nutrition. 64. pp. 115-123. https://www.nature.com/articles/ejcn2009111\#t4 (letöltés ideje: 2018. 11. 08.)

[10] É. Martos (2002) Sporttáplálkozás vagy néptáplálkozás. Magyar Sporttudományi Szemle. 3 (2) pp. 11-13

[11] Európai Sport Charta

[12] Fogalomtár (2018) https://fogalomtar.aeek.hu/index.php/Eg\%C3\%A9szs\%C3\%A9gtudatos_magatart\%C3\%A1 (letöltés ideje: 2018.11 .04 )

[13] G. Pavlik (2015) A rendszeres fizikai aktivitás szerepe betegségek megelőzésében, az egészség megörzésében. Egészségtudomány. 9 (2) 
[14] I. Janssen - A. LeBlanc (2010) Systematic Review of the Health Benefits of Physical activity and Fitness in School-aged children and Youth. International Journal of Behavioral Nutrition and Physical Activity. 2010. May, 7 (40) https://doi. org/10.1186/1479-5868-7-40 (letöltés ideje: 2018. 11.04.)

[15] I. Vajda - Zs. Major - M. Moravecz - K. Pásztorné Batta - T. Vajda - F. V. Vajda - D. Oláh - A. Nagy (2018) Study on physical activity and health behaviour among students at the University of Nyíregyháza. Magyar Sporttudományi Szemle. 19 (2) pp. 22-26

[16] J. Bősze (2007) Az egészségfejlesztés tendenciái világviszonylatban és hazánkban. Magyar Sporttudományi Szemle. 8 (2) pp. 47-51.

[17] J. Vitrai - M. Bakacs - P. Varsányi (2017) Hazai egészség-pillanatkép, 2017 Egészségfejlesztés. $2017.58(4)$

[18] K. András (2006) A szabadidősport gazdaságtana. Budapest Corvinus Egyetem Vállalatgazdaságtan Intézet. 75. sz. Műhelytanulmány. HU ISSN 1786-3031, 58. p.

[19] K. Dudás (2011a) A tudatos fogyasztói magatartás dimenziói. Vezetéstudomány. 42 (7-8)

[20] K. Dudás (2011b) Napjaink egyik jellemző trendje, a tudatos fogyasztás értelmezése. Társadalomkutatás. 29 (3)

[21] K. Dudás (2015) Az egészségtudatos vásárlói magatartás jellemzői - szakirodalmi összefoglalás. Pécsi Tudományegyetem.

[22] K. Kovács (2016) Közép-kelet-európai hallgatók sportolásának szociokulturális jellemzői. IN Értékteremtő Testnevelés - Tanulmányok a testnevelés és a sport szerepéről a Kárpát-medencei fiatalok életében. Debreceni Egyetemi Kiadó.

[23] L. Fodor (2013) Az egészségmagatartás pszichopedagógiai megközelítése, Magiszter, 2013. ősz, pp. 14-22. http://rmpsz.ro/uploaded/tiny/files/magiszter/2013/osz/3.pdf (letöltés ideje: 2018. 11. 04.)

[24] L. Tóthné Parázsó (2011): A kutatásmódszertan matematikai alapjai. Eszterházy Károly Főiskola.

[25] M. Kozma - Á. Szabó - P. Huncsik (2016) A budapesti egyetemisták sportolási szokásai - 20042014. IN Értékteremtő Testnevelés - Tanulmányok a testnevelés és a sport szerepéről a Kárpátmedencei fiatalok életében. Debreceni Egyetemi Kiadó.

[26] M. Niva (2007) All Foods Affect Health': Understandings of Functional Foods and Healthy Eating Among Health-Oriented Finns, Appetite. 2007. 48 pp. 384-393.

[27] N. Keresztes - B. Pikó (2008) Fiatalok sportolási és táplálkozási szokásainak összefüggése Donovan koherencia-elmélete tükrében. Magyar Sporttudományi Szemle. 9 (1) pp. 14-19

[28] NEFI (2015) Egészségjelentés https://www.researchgate.net/publication/292982136_Egeszsegjelentes2015 (letöltés ideje: 2018. 11.08.)

[29] NEFI (2016) Egészségjelentés, http://www.egeszseg.hu/szakmai_oldalak/assets/cikkek/1705/egeszsegjelentes-2016.pdf (letöltés ideje: 2018. 11. 08.)

[30] OECD Jelentés (2019): https://infostart.hu/eletmod/2018/10/10/oecd-a-magyarokszamitanak-europa-legelhizottabb-nemzetenek (letöltés ideje: 2019. 04. 10.)

[31] OTÁP (2014) https://www.ogyei.gov.hu/otap_2014/ (letöltés ideje: 2018. 11. 08.)

[32] OTÁP Konferencia (2016) Infografika az OTÁP vizsgálati eredményei alapján https://www.ogyei.gov.hu/dynamic/otap_testsulyxjavit.pdf (letöltés ideje: 2018. 11. 08.) 
[33] P. Ács - R. Hécz - D. Paár - M. Stocker (2011) A fittség (m)értéke, A fizikai inaktivitás nemzetgazdasági terhei Magyarországon. Közgazdasági Szemle. 58. pp. 689-708.

[34] P. Ács - V. Prémusz - Cs. Melczer - J. Bergier - F. Salonna - J. Junger - A. Makai (2018) Nemek közötti különbségek vizsgálata a fizikai aktivitás vonatkozásában a V4 országok egyetemista populációjának körében. Magyar Sporttudományi Szemle. 19 (2) pp. 3-9.

[35] P. Fritz - N. Mészáros - D. Ignits - S. Katona (2017) A fehérjék táplálkozás-élettani hatása, szerepük a sporttáplálkozásban. Recreation. 7 (3) pp. 10-12.

[36] S. Kasl - S. Cobb (1966) Health Behaviour, Illness Behaviour, and Sick-Role Behaviour. Archives of Environmental Health: An International Journal. 12. pp. 531-541. https://doi.org/10.1080/00039896.1966.10664421 (letöltés ideje: 2018. 11. 04.)

[37] Special Eurobarometer 412 (2014) Sport and physical activity, https://doi.org/10.2766/73002 (letöltés ideje: 2018. 11.08.)

[38] Special Eurobarometer 472 (2018) Sport and physical activity, https://doi.org/10.2766/483047 (letöltés ideje: 2018. 11.08.)

[39] WHO (2003) Food based dietary guidelines in the WHO European Region, Nutrition and Food Security Programme

[40] WHO Jelentés (2018): https://www.who.int/news-room/fact-sheets/detail/healthy-diet (letöltés ideje: 2018.11.19)

[41] Z. Szakály (2008) Trendek és tendenciák a funkcionális élelmiszerek piacán: Mit vár el a hazai fogyasztó?. Élelmiszer, Táplálkozás és Marketing. No. 2-3.

[42] Zs. Mednyánszky (2002) Zöldség- és gyümölcsfélék a sportolók táplálkozásában. Magyar Sporttudományi Szemle. 3 (2) pp. 23-24. 